\title{
Adipose TSHB in Humans and Serum TSH in Hypothyroid Rats Inform About Cellular Senescence
}

\author{
José María Moreno-Navarrete ${ }^{a}$ Laura Liñares-Pose ${ }^{b} \quad$ Mònica Sabater ${ }^{a}$ \\ Eva Rial-Pensado ${ }^{b}$ Ferran Comas ${ }^{a}$ Mariona Jovéc Jèssica Latorre ${ }^{a}$ \\ Francisco Ortega ${ }^{a} \quad$ Wifredo Ricarta ${ }^{a} \quad$ Manuel Portero-Otin ${ }^{c} \quad$ Miguel López $^{b}$ \\ José Manuel Fernández-Real ${ }^{a^{*}}$ \\ aDepartment of Diabetes, Endocrinology and Nutrition Institut d'Investigació Biomèdica de Girona \\ (IdIBGi), CIBEROBN (CB06/03/010) and Instituto de Salud Carlos III (ISCIII), Girona, ' $N$ NeurObesity Group, \\ Department of Physiology, CIMUS, University of Santiago de Compostela-Instituto de Investigación \\ Sanitaria, Santiago de Compostela, CIBER Fisiopatología de la Obesidad y Nutrición (CIBERobn), \\ Santiago de Compostela, cNutrició i Envelliment (NUTREN)-Nutrigenomics, Institut de Recerca \\ Biomèdica de Lleida (IRBLLEIDA)-UdL, Científic i Tecnològic Agroalimentari de Lleida (PCiTAL), Lleida, \\ Spain
}

\section{Key Words}

Thyroid-stimulating hormone - Euthyroidism - Hypothyroidism - Adipose tissue • Cellular senescence

\begin{abstract}
Background/Aims: Thyroid hormones have been recently linked to senescence and longevity. Given the recent description of TSHB mRNA in human adipose tissue (AT), we aimed to investigate the relationship between local AT TSH and adipose tissue senescence. Methods: TSHB MRNA (measured by real-time PCR) and markers of adipose tissue senescence [BAX, $D B C 1, T P 53, T N F$ (real-time PCR), telomere length (Telo TAGGG Telomere Length Assay) and lipidomics (liquid chromatography mass spectrometry)] were analysed in subcutaneous (SAT) and visceral (VAT) AT from euthyroid subjects. The chronic effects of TSH were also investigated in AT from hypothyroid rats and after recombinant human TSH (rhTSH) administration in human adipocytes. Results: Both VAT and SAT TSHB gene expression negatively correlated with markers of AT cellular senescence (BAX, DBC1, TP53, TNF gene expression and specific glucosylceramides) and positively associated with telomere length. Supporting these observations, both rhTSH administration in human adipocytes and increased TSH in hypothyroid rats resulted in decreased markers of cellular senescence (Bax and Tp53 mRNA) in both gonadal and subcutaneous white adipose tissue. Conclusion: These data point to a possible role of TSH in AT cellular senescence.




\section{Cellular Physiology Cell Physiol Biochem 2018;51:142-153

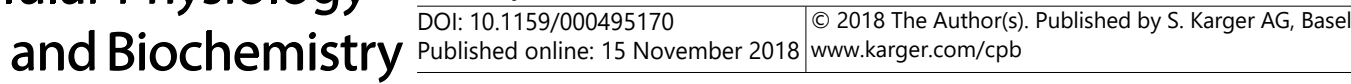 \\ Moreno-Navarrete et al.: TSH and Adipose Tissue Senescence}

\section{Introduction}

Thyroid function is well known to be involved in longevity and senescence [1-9] and in energy balance [10]. Different animal models characterized by increased longevity had in common the following hormonal and metabolic characteristics: 1) reduced thyroid function (absent TSH and severely reduced thyroid hormone in Ames and Snell dwarf mice, in naked mole-rat and calorie-restricted rats), 2) reduced basal metabolic rate, and 3) reduced core body temperature. A causal relationship between thyroid function and longevity was further demonstrated by experimental induction of hypothyroidism in rats, which resulted in extended life span. Conversely, inducing hyperthyroidism resulted in significantly shorter life span [4-6].

In humans, the relationship between hypothyroidism and increased life expectancy has also been observed [4-9]. Euthyroid 50 year-old participants with increased levels of TSH had a longer life expectancy than participants with decreased serum TSH levels [4]. Increased TSH levels were also associated with lower mortality in participants between ages 85 and 90 [5] and in their offspring [6], and even in centenarians [7, 8]. In fact, increased familial longevity is characterized by higher TSH secretion, without altering whole body energy metabolism [9].

Adipose tissue cellular senescence is characterized by increased expression of apoptotic and senescence markers (caspase induction leading to increased BAX, TP53 and DBC1 expression), decreased telomere length [11-15], and impaired capacity to generate new adipocytes and mitochondrial dysfunction [12-14].

We hypothesized that TSH might modulate AT senescence. Given the recent description of TSHB mRNA in human AT [16], the potential associations of TSHB mRNA with markers of AT senescence were explored. Then, the impact of recombinant human (rh)TSH in human adipocytes and of chronic serum TSH elevation (induced by aminotriazole) on AT senescence in rats was evaluated.

\section{Materials and Methods}

\section{Patient recruitment}

Forty-five paired SAT and VAT samples from euthyroid morbidly obese (BMI $>35 \mathrm{~kg} / \mathrm{m}^{2}$ ) subjects (Cohort 1) were studied. All these subjects were recruited at the Endocrinology Service of the Hospital of Girona "Dr Josep Trueta", were of Caucasian origin and reported that their body weight had been stable for at least three months before the study. Subjects were studied in the post-absorptive state. BMI was calculated as weight (in $\mathrm{kg}$ ) divided by height (in $\mathrm{m}$ ) squared. Patients had no systemic disease other than obesity and all were free of any infections in the previous month before the study. Liver diseases (specifically tumoral disease and HCV infection) and thyroid dysfunction were specifically excluded by biochemical work-up. All subjects gave written informed consent, validated and approved by the Ethical Committee of the Hospital of Girona "Dr Josep Trueta", after the purpose of the study was explained to them. Samples and data from patients included in this study were partially provided by the FATBANK platform promoted by the CIBEROBN and coordinated by the IDIBGI Biobank (Biobanc IDIBGI, B.0000872), integrated in the Spanish National Biobanks Network and they were processed following standard operating procedures with the appropriate approval of the Ethics, External Scientific and FATBANK Internal Scientific Committees.

\section{Adipose tissue handling}

Adipose tissue samples were obtained from SAT and VAT depots during elective surgical procedures (cholecystectomy, surgery of abdominal hernia and gastric by-pass surgery). Samples of adipose tissue were immediately transported to the laboratory (5-10 min). The handling of tissue was carried out under strictly aseptic conditions. Adipose tissue samples were washed in PBS, cut off with forceps and scalpel into small pieces $(100 \mathrm{mg})$, and immediately flash-frozen in liquid nitrogen before being stored at $-80 \stackrel{\circ}{\mathrm{C}}$. 


\section{Cellular Physiology Cell Physiol Biochem 2018;51:142-153 \begin{tabular}{l|l|l} 
and Biol: 10.1159/000495170 & 2018 The Author(s). Published by S. Karger AG, Basel
\end{tabular}}

Moreno-Navarrete et al.: TSH and Adipose Tissue Senescence

\section{In vitro experiments}

Isolated human visceral preadipocytes from obese subjects (BMI> 30) were purchased in a specialized company (Zen-Bio Inc., Research Triangle Park, NC, USA) and were cultured $\left(\sim 40.000\right.$ cells $\left./ \mathrm{cm}^{2}\right)$ with pre-adipocyte medium (Omental/Visceral Preadipocyte Medium, Item\# OM-PM, Zen-Bio Inc.) composed of DMEM/Nutrient Mix F-12 medium (1:1, v/v), HEPES, FBS, Penicillin and Streptomycin in a humidified $37^{\circ} \mathrm{C}$ incubator with $5 \% \mathrm{CO}$. Adipocyte differentiation was performed as described elsewhere [17]. Briefly, twenty-four hours after plating, cells were checked for confluence (day 0th) and differentiation was induced using differentiation medium (Omental/Visceral Preadiopcyte Differentiation Medium, Item\# OM-DM, ZenBio Inc) composed of OM-PM, human Insulin, dexamethasone (DXM), isobutylmethylxanthine (IBMX) and PPAR $\gamma$ agonists (rosiglitazone). After 7 days (day 7), OM-DM was replaced with fresh adipocyte medium (Omental/Visceral Adipocyte Maintenance Medium, Item\# OM-AM, Zen-Bio Inc.,) composed of DMEM/ Nutrient Mix F-12 medium (1:1, v/v), HEPES, FBS, Biotin, panthothenate, human insulin, DXM, Penicillin, Streptomycin and amphotericin. Fourteen days after the initiation of differentiation, cells appeared rounded with large lipid droplets apparent in the cytoplasm. Cells were then considered mature adipocytes. Recombinant human TSH $\alpha / \beta$ (rhTSH, 1 and $10 \mathrm{mU} / \mathrm{l}$ ) was administrated on differentiated visceral adipocytes during 2 and 7 days. Then, cells were harvested and stored at $-80^{\circ} \mathrm{C}$ for RNA extraction to study gene expression levels. The experiment was performed in triplicate for each sample.

\section{Experiments in rats}

Adult male Sprague-Dawley rats (250-300 g; Animalario General USC; Santiago de Compostela, Spain) were housed on a $12 \mathrm{~h}$ light (8:00 to 20:00), $12 \mathrm{~h}$ dark cycle, in a temperature- and humidity-controlled room. Animals were allowed free access to standard laboratory pellets of rat chow and tap water. Hypothyroidism was induced as previously described [18-20] by administration of $0.1 \%$ aminotriazole (Sigma, St Louis MO, USA) in drinking water for a period of one, two and three weeks. Eight rats per experimental group were used. Body weight and food intake were recorded twice per week. At the end of the treatment rats were killed by cervical dislocation and the tissues quickly harvested and stored at $-80{ }^{\circ} \mathrm{C}$ until processing. The experiments were performed in agreement with the International Law on Animal Experimentation and were approved by the USC Ethical Committee (Project ID 15010/14/006).

\section{RNA expression}

RNA purification, gene expression procedures and analyses were carried out, as previously described [13]. Briefly, RNA purification was performed using the RNeasy Lipid Tissue Mini Kit (QIAgen, Izasa SA, Barcelona, Spain) and the integrity was checked by the Agilent Bioanalyzer (Agilent Technologies, Palo Alto, CA). Gene expression was assessed by real-time PCR using a LightCycler ${ }^{\circledast} 480$ Real-Time PCR System (Roche Diagnostics SL, Barcelona, Spain), using TaqMan ${ }^{\circledR}$ and SYBRgreen technology suitable for relative genetic expression quantification.

The commercially available and pre-validated TaqMan ${ }^{\circledR}$ primer/probe sets were used as follows: Peptidylprolyl isomerase A (cyclophilin A) (4333763, PPIA as endogenous control), thyroid stimulating hormone beta (TSHB, Hs02759015_s1), tumor necrosis factor (TNF, Hs00174128_m1), BCL2-associated X protein (BAX, Hs00180269_m1), tumor protein p53 (TP53, Hs01034249_m1) and cell cycle activator and apoptosis regulator 2 (CCAR2 or DBC1, Hs00368356_m1), and in rats, Bcl2-associated X protein (Bax, Rn01480161_g1) and tumor protein p53 (Tp53, Rn00755717_m1).

\section{Telomere length measurement}

In a subgroup of participants $(\mathrm{n}=22)$ in that adipose tissue DNA was available telomere length was measured as described elsewhere [14]. Briefly, total DNA purification from subcutaneous adipose tissue was performed using the phenol-chloroform method. Frozen adipose subcutaneous tissue was homogenized with lysis buffer containing proteinase $\mathrm{K}$ for $30 \mathrm{~s}$. The homogenate was incubated at $56^{\circ} \mathrm{C}$ for $1 \mathrm{~h}$ and centrifuged at $13,000 \mathrm{~g}$ at $4{ }^{\circ} \mathrm{C}$ for $15 \mathrm{~min}$. The infranatant fraction was added and mixed in phenol:chloroform:isoamil solution, and centrifuged at $5,000 \mathrm{~g}$ at $4{ }^{\circ} \mathrm{C}$ for $15 \mathrm{~min}$. Total DNA was quantifed by means of spectrophotometer (GeneQuant; GE Healthcare, Piscataway, NJ). Telomere length was measured by Telo TAGGG Telomere Length Assay (Roche, Penzberg, Germany), according to manufacturer's instructions. Purified genomic DNA was digested by an optimized mixture of frequently cutting restriction enzymes, which digested to low molecular weight fragments nontelomeric DNA. Following DNA digestion, 


\section{Cellular Physiology Cell Physiol Biochem 2018;51:142-153 and Biochemistry \begin{tabular}{l|l} 
DOI: $10.1159 / 000495170$ & (c) 2018 The Author(s). Published by S. Karger AG, Basel \\
www.karger.com/cpb
\end{tabular}

the DNA fragments were separated by gel electrophoresis and transferred to a nylon membrane by Southern blotting. The blotted DNA fragments were hybridized to a digoxigenin-labeled probe-specific for telomeric repeats and incubated with a digoxigenin-specific antibody covalently coupled to alkaline phosphatase. Finally, the immobilized telomere probe was visualized by virtue of alkaline phosphatase metabolizing CDPStar, a highly sensitive chemiluminescent substrate. The average terminal restriction fragments length was determined by comparing the signals relative to a molecular weight standard.

\section{Lipidomic analyses}

Lipidomic analyses were performed as described elsewhere [16], in a subsample of 12 consecutive subjects from Cohort 1 . Briefly, 35-50 mg samples of SAT $(n=12)$ were homogenized in 20 volumes (v/w) cold methanol (with BHT $1 \mu \mathrm{M})(1: 20 \mathrm{w}: \mathrm{v})$ at $4^{\circ} \mathrm{C}$. Thereafter, we added 20 volumes of lysis buffer (containing 80 $\mathrm{mM} \mathrm{KCl}, 5 \mathrm{mM}$ EDTA, and $1 \mathrm{mM}$ diethylenetriaminepentaacetic acid; pH 7.3) and 40 volumes of chloroform containing representative internal standards class lipids. The characteristics of these subjects did not differ significantly from the whole cohort. The chloroform phase was injected in a LC-MS system (UPLC 1290 couple to QTOF 6520 Agilent Technologies, Santa Clara, CA, USA). This method allows the orthogonal characterization [based on exact mass $(<10 \mathrm{ppm})$ and on retention time] of lipids. When combined with internal standards, this strategy is useful for attributing potential identities with low uncertainty. Data were collected in both positive and negative electrospray ionization-Q-TOF operated in full-scan mode at $100-3000 \mathrm{~m} / \mathrm{z}$ in an extended dynamic range $(2 \mathrm{GHz})$, using $\mathrm{N} 2$ as nebulizer gas $\left(5 \mathrm{~L} / \mathrm{min}, 300^{\circ} \mathrm{C}\right)$. The capillary voltage was $3500 \mathrm{~V}$ with a scan rate of $1 \mathrm{scan} / \mathrm{s}$. Targeted lipidomic approach was chosen to detect the abundance of specific senescence-associated glucosylceramides [21].

\section{Analytical methods}

Serum glucose concentrations were measured in duplicate by the glucose oxidase method using a Beckman glucose analyser II (Beckman Instruments, Brea, California). Roche Hitachi Cobas c711 instrument (Roche, Barcelona, Spain) was used to perform HDL-cholesterol and total serum triglycerides determinations. HDL-cholesterol was quantified by a homogeneous enzymatic colorimetric assay through the cholesterol esterase /cholesterol oxidase /peroxidase reaction (Cobas HDLC3). Serum fasting triglycerides were measured by an enzymatic, colorimetric method with glycerol phosphate oxidase and peroxidase (Cobas TRIGL). LDL-cholesterol was calculated using the Friedewald formula.

\section{Statistical analyses}

Statistical analyses were performed using SPSS 12.0 software. Unless otherwise stated, descriptive results of continuous variables are expressed as mean and SD for Gaussian variables or median and interquartile range. Parameters that did not fulfil normal distribution criteria were Log transformed to improve symmetry for subsequent analyses. The relation between variables was analyzed by simple correlation (Pearson's test and Spearman's test). Levels of statistical significance were set at $\mathrm{p}<0.05$.

\section{Results}

AT TSHB mRNA is linked to AT cellular senescence in humans

In euthyroid morbidly obese subjects (Table 1), both SAT and VAT TSHB gene expression was negatively associated with markers of AT senescence (TNF, TP53, BAX and DBC1) (Table 2, Fig. 1AD). Confirming these findings, SAT TSHB mRNA was positively linked to telomere

Table 1. Anthropometric and clinical parameters and VAT and SAT TSHB gene expression in human cohort. ${ }^{\mathrm{a}}$ Mean $\pm \mathrm{SD}$; ${ }^{\mathrm{b}}$ Median (interquartile range); VAT, Visceral Adipose Tissue; SAT, Subcutaneous Adipose Tissue

\begin{tabular}{|c|c|}
\hline COHORT 1 & All participants \\
\hline $\mathrm{N}$ & 45 \\
\hline Sex (men/women) & $10 / 35$ \\
\hline Age (years) & $47.5 \pm 8.6$ \\
\hline BMI $\left(\mathrm{kg} / \mathrm{m}^{2}\right)^{\mathrm{a}}$ & $45.1 \pm 7.1$ \\
\hline Fasting glucose $(\mathrm{mg} / \mathrm{dl})^{\mathrm{b}}$ & $98(90-107)$ \\
\hline Total cholesterol (mg/dl)a & $190(165-213)$ \\
\hline LDL cholesterol (mg/dl)a & $122(100.5-145.5)$ \\
\hline HDL cholesterol (mg/dl)a & $46(40-50.5)$ \\
\hline Fasting triglycerides $(\mathrm{mg} / \mathrm{dl})^{\mathrm{b}}$ & $120(80-153.5)$ \\
\hline Serum TSH $(\mathrm{mU} / \mathrm{l})^{\mathrm{b}}$ & $2.05(1.39-2.92)$ \\
\hline VAT TSHB (RU) ${ }^{\mathrm{b}}$ & $0.00043(0.00013-0.00641)$ \\
\hline SAT TSHB (RU) ${ }^{\mathrm{b}}$ & $0.00227(0.00012-0.00552)$ \\
\hline
\end{tabular}


length in a subgroup of consecutive subjects $(r=0.43, p=0.04, n=22 ;$ Fig. 2 A), suggesting decreased senescence with less exposure to thyroid hormones. Furthermore, SAT TSHB mRNA was negatively correlated to specific senescence-associated glucosylceramides (Fig. 2B-D).

A positive correlation between adipose tissue TSHB and PPARGC1A mRNA has been recently reported [22]. Interestingly, in both SAT and VAT, PPARGC1A was negatively correlated with TP53 $(\mathrm{r}=-0.44, \mathrm{p}=0.01$ in SAT and $\mathrm{r}=-0.42, \mathrm{p}=0.02$ in VAT) and $B A X$ $(\mathrm{r}=-0.55, \mathrm{p}=0.001$ in SAT and $\mathrm{r}=-0.39$, $\mathrm{p}=0.04$ in VAT) gene expression.

\section{In vitro experiments}

In vitro experiments in differentiated visceral adipocytes indicated that while long-term (7 days) $\mathrm{rhTSH}(1$ and $10 \mathrm{mU} / \mathrm{l})$ administration resulted in a significant decreased cellular senescence-related (DBC1, TNF, BAX and TP53) gene expression (Fig. 3A-D), no significant effects of short-term (2 days) rhTSH administration on expression of these genes were observed (Fig. 3E-H).
Table 2. Bivariate correlations between VAT and SAT TSHB gene expression, clinical parameters and expression of adipose tissue-related genes in human cohort

\begin{tabular}{lccccc}
\hline & \multicolumn{3}{c}{ SAT } & \multicolumn{2}{c}{ VAT } \\
& $\mathrm{N}$ & $\mathrm{r}$ & $\mathrm{p}$ & $\mathrm{r}$ & $\mathrm{p}$ \\
\hline Age (years) & 45 & -0.10 & 0.5 & -0.09 & 0.6 \\
BMI (kg/m²) & 45 & -0.05 & 0.7 & 0.19 & 0.2 \\
Fasting glucose (mg/dl) & 45 & -0.35 & 0.01 & -0.26 & 0.1 \\
Total cholesterol (mg/dl) & 45 & 0.15 & 0.3 & 0.36 & 0.02 \\
LDL cholesterol (mg/dl) & 45 & 0.13 & 0.4 & 0.43 & 0.006 \\
HDL cholesterol (mg/dl) & 45 & -0.07 & 0.6 & -0.16 & 0.3 \\
Fasting triglycerides (mg/dl) & 45 & 0.15 & 0.3 & 0.11 & 0.5 \\
Serum TSH (mU/l) & 45 & 0.11 & 0.4 & -0.09 & 0.6 \\
DBC1 (RU) & 43 & -0.46 & 0.002 & -0.59 & $<0.0001$ \\
TNF (RU) & 43 & -0.62 & $<0.0001$ & -0.47 & 0.005 \\
BAX (RU) & 33 & -0.48 & 0.005 & -0.54 & 0.001 \\
TP53 (RU) & 33 & -0.46 & 0.007 & -0.45 & 0.009 \\
\hline
\end{tabular}

Fig. 1. A-F)

B iv a ri a te correlations b e $t w$ e e $n$ SAT TSHB and TNF (A), DBC1 (B), TP53 and $B A X$ (D) mRNA levels.
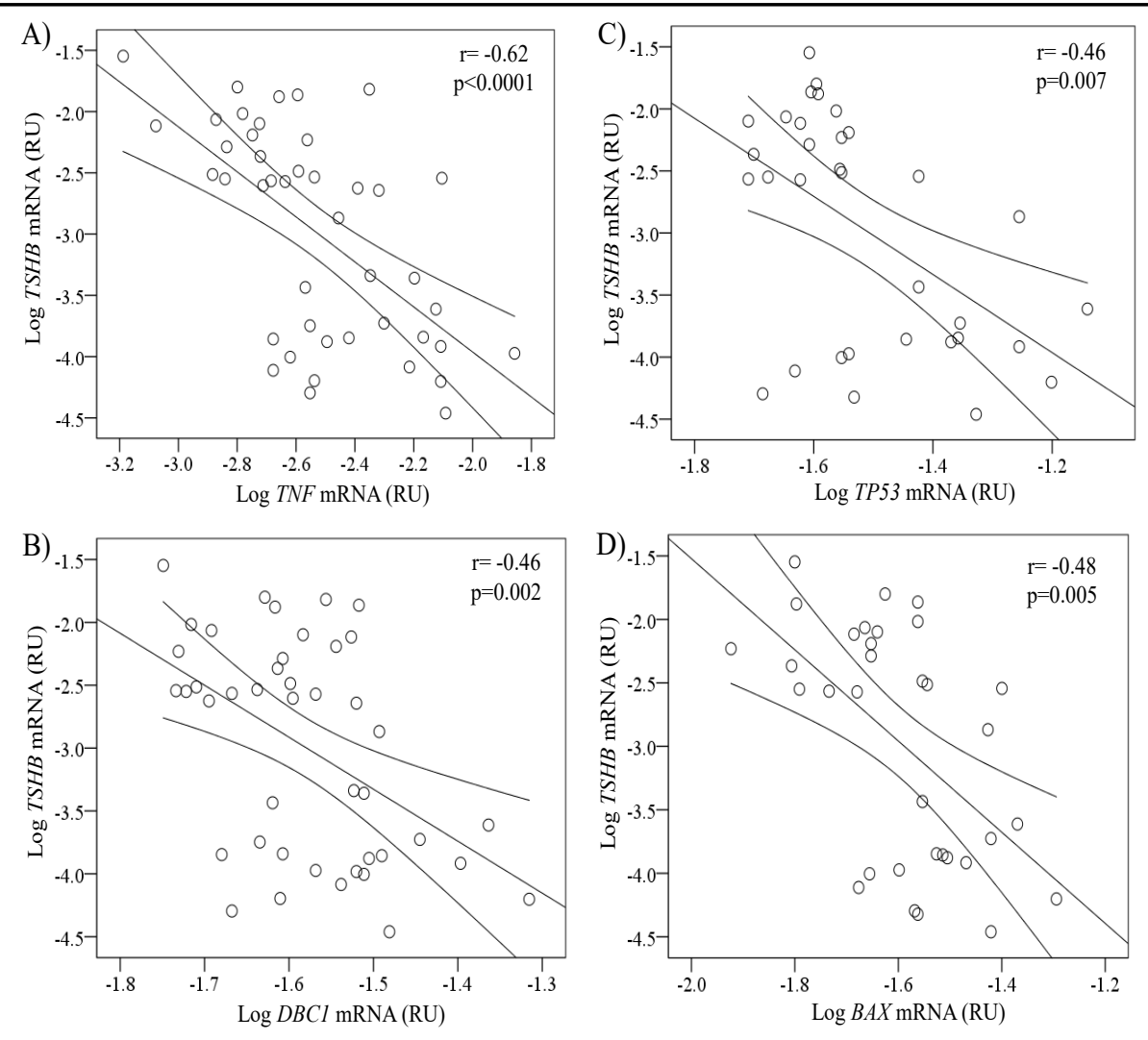
Moreno-Navarrete et al.: TSH and Adipose Tissue Senescence

Fig. 2. Bivariate c orre lations between SAT TSHB and telomere length $(\mathrm{n}=22) \quad$ (A) and specific senescencea s s o c i a t e d glucosylceramides $[\mathrm{N}=12$, except GlcCer(d18/25:0), which was not detected in one participant] (B-D).
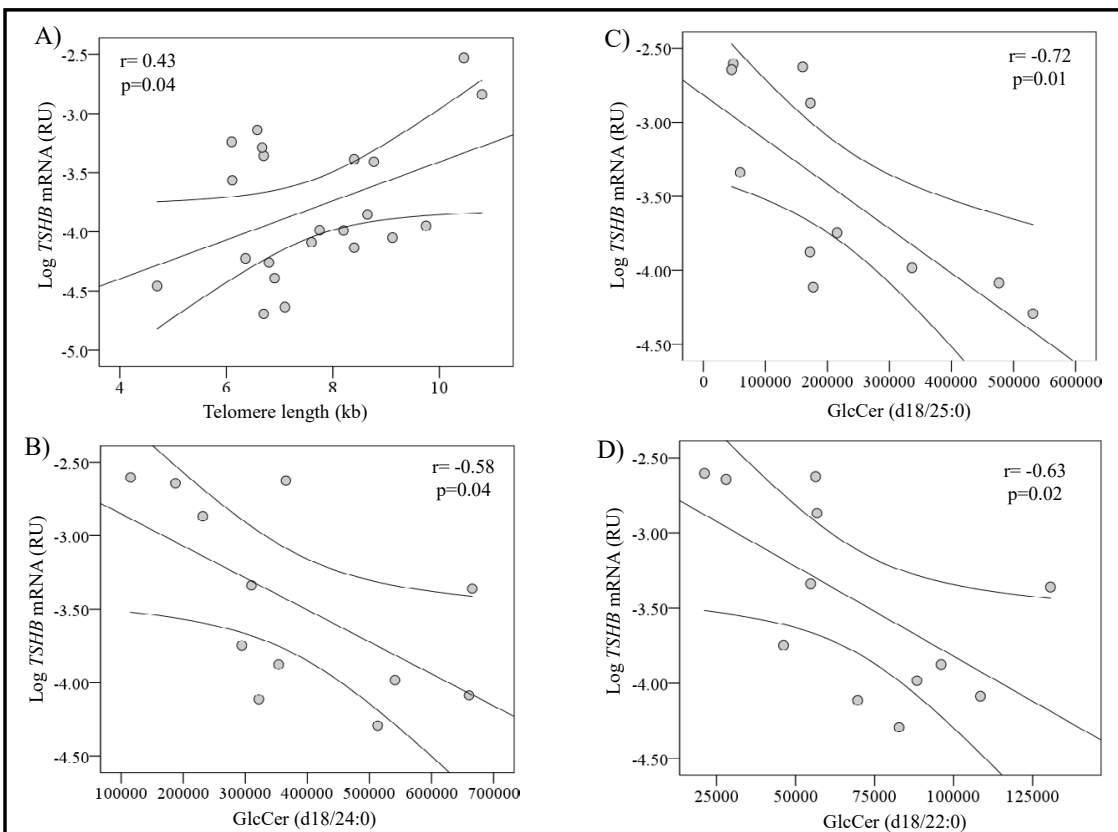
GlcCer (d18/25:0)

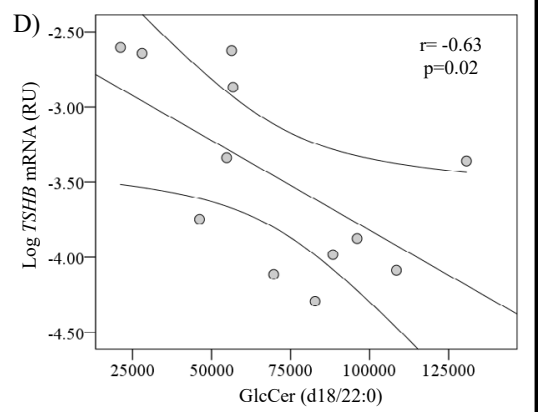

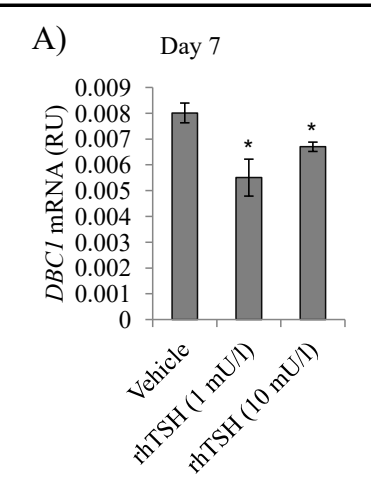

E)
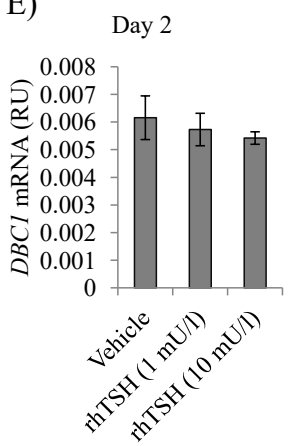

B)

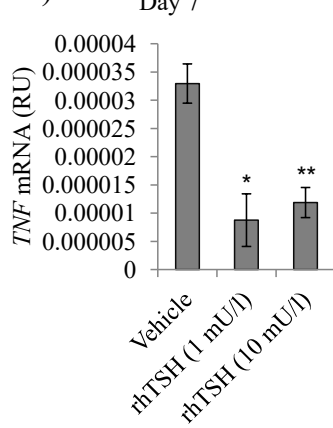

F)

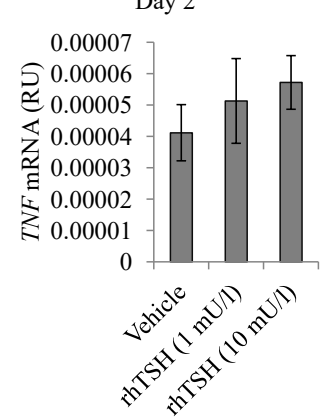

C)

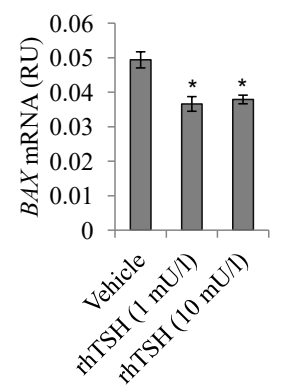

G)

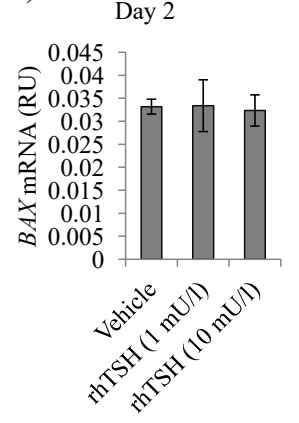

D)
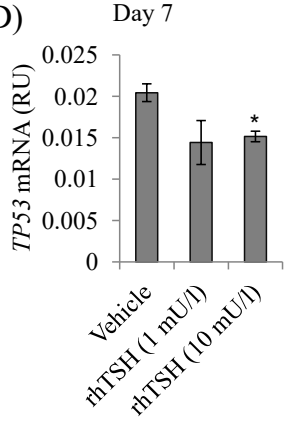

H)

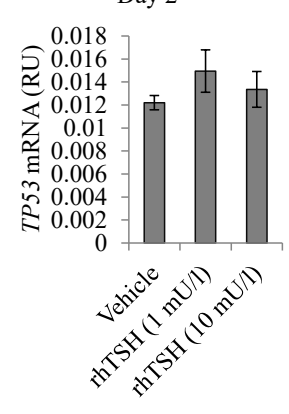

Fig. 3. A-D) Effects of rhTSH ( 1 and $10 \mathrm{mU} / \mathrm{l}$ ) administration during 7 (A-D) or 2 (E-H) days on $D B C 1$ (A,E), $T N F(\mathrm{~B}, \mathrm{~F}), B A X(\mathrm{C}, \mathrm{G})$ and $T P 53(\mathrm{D}, \mathrm{H}) \mathrm{mRNA}$ levels in visceral adipocytes. ${ }^{*} \mathrm{p}<0.05$ and ${ }^{* *} \mathrm{p}<0.01$ vs. vehicle. 


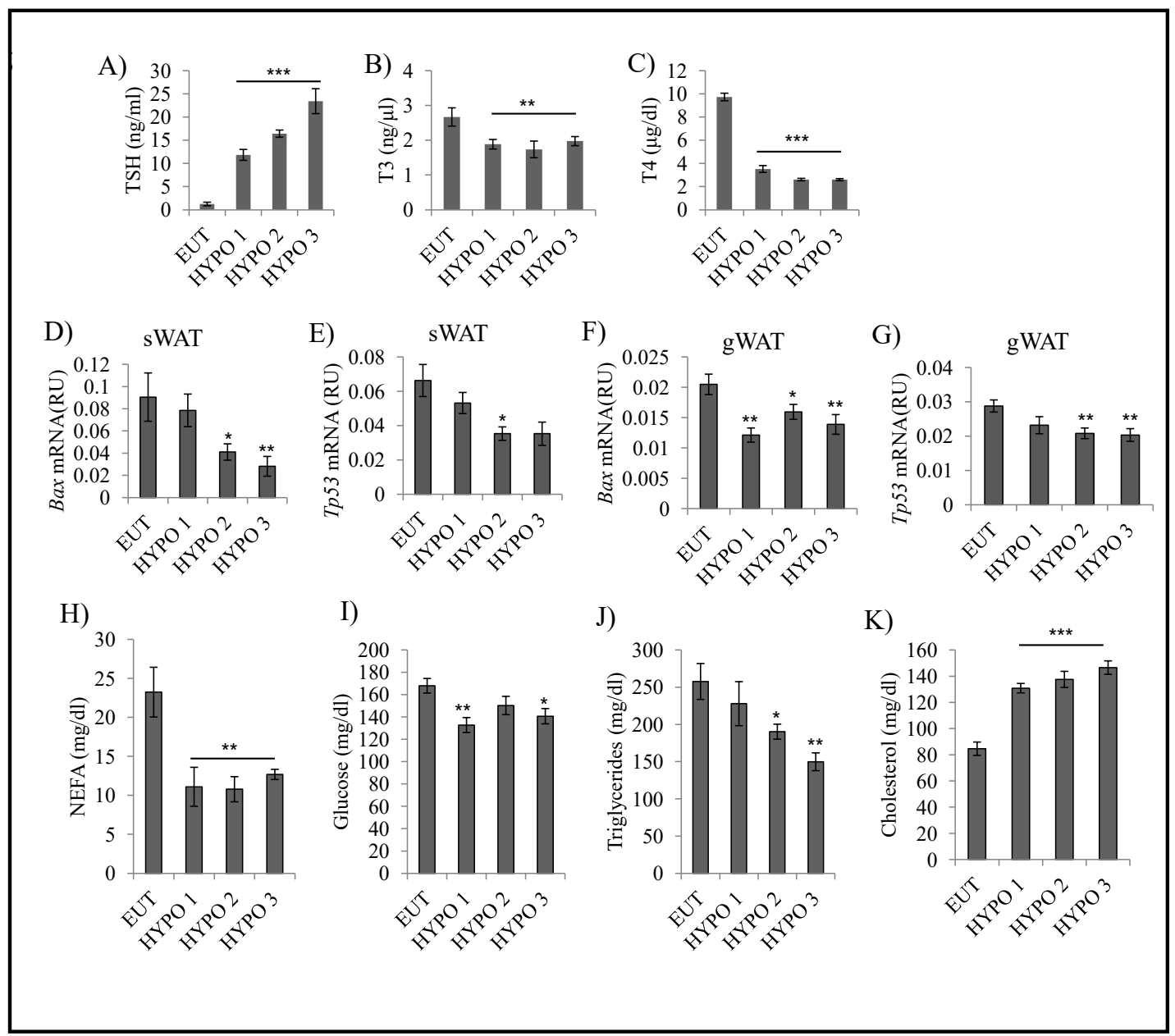

Fig. 4. A-K) Effects of amino-triazole administration during 1 (HYPO1), 2 (HYPO2) and 3 (HYPO3) weeks on serum TSH (A), T3 (B), T4 (C), on sWAT and gWAT Bax and Tp53 mRNA levels (D-G) and on serum NEFA $(\mathrm{H})$, glucose $(\mathrm{I})$, triglycerides $(\mathrm{J})$ and cholesterol $(\mathrm{K})$ levels. EUT were non-treated or control rats. ${ }^{*} \mathrm{p}<0.05$, ${ }^{* *} \mathrm{p}<0.01$ and ${ }^{* * *} \mathrm{p}<0.001$ vs EUT rats.

\section{Chronically increased TSH levels impact on AT cellular senescence in rats}

Next, to explore the impact of increased serum TSH levels on AT cellular senescence, we evaluated the effects of chronic increased TSH levels exposure in an aminotriazole-induced hypothyroidism rat model. Of note, both increased circulating TSH levels (Fig. 4A) and decreased T4 and T3 levels (Fig. 4B-C), were associated with decreased markers of cellular senescence (Bax and Tp53 mRNA) in gonadal and subcutaneous white adipose tissue (Fig. 4D-G). Aminotriazole-induced hypothyroidism also resulted in decreased circulating glucose, NEFAs and triglycerides, as well as elevated cholesterol (Fig. 4H-K).

\section{Discussion}

Increased TSH mRNA levels and circulating TSH were significantly associated with reduced markers of cellular senescence (including $B A X, D B C 1, T P 53, T N F$ gene expression $[12,13]$ and specific glucosylceramides $[21,23])$ and increased telomere length in both human and rat AT. These data agree with the positive association between serum TSH levels and longevity reported in rodents [1-3] and euthyroid humans [3-9]. In line with these observations, rhTSH administration in human visceral adipocytes during 7 days, but not 


\section{Cellular Physiology Cell Physiol Biochem 2018;51:142-153

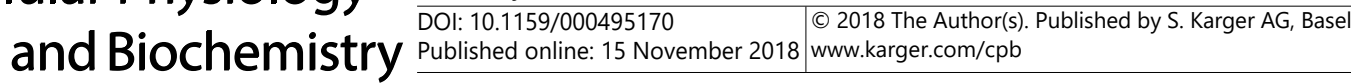 \\ Moreno-Navarrete et al.: TSH and Adipose Tissue Senescence}

during 2, resulted in decreased expression of cellular senescence-related gene markers. In parallel with these findings, a recent publication demonstrated that TSH administration (48h) in fully differentiated human adipocytes resulted in a significant improvement of mitochondrial biogenesis and function, increasing basal respiration, ATP production and spare respiratory capacity in parallel to increased SIRT1 and mitochondrial biogenesisrelated gene markers [22]. Furthermore, this study also demonstrated that TSHB mRNA was positively correlated with mitochondrial function-related (PPARGC1A and SIRT1) gene expression in human adipose tissue [22]. PPARGC1A is a transcriptional coactivator that modulates the genes involved in energy metabolism, being a central regulator of mitochondria biogenesis [24-27]. SIRT1, which is another important mediator of mitochondrial biogenesis and energy expenditure in AT [27-29], is widely known as a negative regulator of cellular senescence [30,31]. In humans, increased AT SIRT1 mRNA levels and activity associates with mitochondrial function [28, 29] and with reduced markers of cellular senescence [32, 33]. Furthermore, DBC1 interacts and inhibits the activity of Sirt1 [34], a crucial component for the prevention of cellular senescence $[35,36]$.

Different studies have shown a negative role of p53 in adipose tissue physiology, decreasing adipocyte differentiation [37-40] and increasing the expression of proinflammatory cytokines via the NF- $\kappa B$ signaling pathway [41], leading to obesity-associated insulin resistance and adipose tissue dysfunction [13, 42-46]. In fact, p53 stimulation in dysfunctional adipose tissue enhanced adiposity-associated metabolic disturbances (such as glucose intolerance) [47], whereas its inhibition has therapeutic effects [48]. Interestingly, a recent study demonstrated that adipose tissue-specific ablation of ACSL4 mice were protected against high fat diet-induced metabolic disturbances and adipose tissue dysfunction and senescence, in parallel to reduced p53 activation and increased adipocyte oxygen consumption [49]. Sen et al. reported in HepG2 cells cultured in conditions of metabolic stresses (such as glucose/serum starvation or cold shock) that PGC1 $\alpha$ interacts with p53, increasing its transcriptional activity of proarrest and metabolic target genes in the first 36 $\mathrm{h}$ of metabolic stresses [50]. At extended periods of metabolic stresses ( 48 and $72 \mathrm{~h}$ ), PGC1 $\alpha$ protein levels drastically decreased, the interaction between PGC1 $\alpha$ and p53 was lost, and p53 transactivates its proapoptotic targets, resulting in cell death [50]. In the present study, PPARGC1A was negatively associated with TP53 and BAX gene expression in both SAT and VAT, supporting that decreased PGC1 $\alpha$ levels enhanced the p53 transcriptional activity of proapoptotic target genes, and in consequence, promoted cellular senescence in adipose tissue. In fact, the contribution of mitochondrial dysfunction to cellular senescence in AT and the negative effects of aging on mitochondrial function are well known [51-53].

Current data and previous study [22] suggested that, mechanistically, the anti-senescence effects of TSH could be mediated through the improvement of adipocyte mitochondrial function.

Supporting all these findings, chronically elevated circulating TSH resulted in protection from AT senescence in rats. Aminotriazole-induced hypothyroidism resulted in decreased serum NEFAs. This data are in agreement with our metabolic characterization of this model showing, decreased fatty acid synthase expression in liver and WAT (the main sources of circulating NEFAS) of hypothyroid rats [20]. In keeping with this, severe hypothyroidism has been very recently described to result in suppression of adipose tissue lipolysis and decreased NEFAs in contrast to mild hypothyroidism [54].

\section{Conclusion}

In conclusion, altogether these data suggest a possible role of adipose tissue TSHB endogenous biosynthesis in the regulation of adipose tissue cellular senescence, possibly through the maintenance of mitochondrial function. 


\section{Cellular Physiology Cell Physiol Biochem 2018;51:142-153 \begin{tabular}{ll|l} 
and Biochemistry Published onlIne: 15 November 2018 & $\begin{array}{l}\text { (c) } 2018 \text { The Author(s). Published by S. Karger AG, Basel } \\
\text { www.karger.com/cpb }\end{array}$ \\
\hline
\end{tabular} \\ Moreno-Navarrete et al.: TSH and Adipose Tissue Senescence}

\section{Acknowledgements}

This work was partially supported by research grant PI15/01934 and PI16/01173 from the Instituto de Salud Carlos III from Spain and was also supported by Fondo Europeo de Desarrollo Regional (FEDER); Xunta de Galicia (ML: 2015-CP079), Ministry of Economy and Competitiveness (ML: SAF2015-71026-R) and AtresMedia. CIBEROBN Fisiopatología de la Obesidad y Nutrición is an initiative from the Instituto de Salud Carlos III from Spain. We acknowledge the technical assistance of E. Loshuertos and O. Rovira (both from Endocrinology, IdIBGi, Spain). We want to particularly acknowledge the patients, the FATBANK platform promoted by the CIBEROBN and the IDIBGI Biobank (Biobanc IDIBGI, B.0000872), integrated in the Spanish National Biobanks Network, for their collaboration and coordination.

\section{Disclosure Statement}

The authors declared no conflicts of interest.

\section{References}

$\checkmark 1$ Ooka H, Shinkai T: Effects of chronic hyperthyroidism on the lifespan of the rat. Mech Ageing Dev 1986;33:275-282.

-2 Brown-Borg HM, Borg KE, Meliska CJ, Bartke A: Dwarf mice and the ageing process. Nature 1996;384:33.

-3 Vergara M, Smith-Wheelock M, Harper JM, Sigler R, Miller RA: Hormone-treated snell dwarf mice regain fertility but remain long lived and disease resistant. J Gerontol A Biol Sci Med Sci 2004;59:1244-1250.

4 Bano A, Dhana K, Chaker L, Kavousi M, Ikram MA, Mattace-Raso FUS, Peeters RP, Franco OH: Association of Thyroid Function With Life Expectancy With and Without Cardiovascular Disease: The Rotterdam Study. JAMA Intern Med 2017;177:1650-1657.

5 Gussekloo J, van Exel E, de Craen AJ, Meinders AE, Frölich M, Westendorp RG: Thyroid status, disability and cognitive function, and survival in old age. JAMA 2004;292:2591-2599.

6 Bowers J, Terrien J, Clerget-Froidevaux MS, Gothié JD, Rozing MP, Westendorp RG, van Heemst D, Demeneix BA: Thyroid hormone signaling and homeostasis during aging. Endocr Rev 2013;34:556-589.

7 Atzmon G, Barzilai N, Hollowell JG, Surks MI, Gabriely I: Extreme longevity is associated with increased serum thyrotropin. J Clin Endocrinol Metab 2009;94:1251-1254.

-8 Rozing MP, Houwing-Duistermaat JJ, Slagboom PE, Beekman M, Frölich M, de Craen AJ, Westendorp RG, van Heemst D: Familial longevity is associated with decreased thyroid function. J Clin Endocrinol Metab 2010;95:4979-4984.

-9 Jansen SW, Akintola AA, Roelfsema F, van der Spoel E, Cobbaert CM, Ballieux BE, Egri P, Kvarta-Papp Z, Gereben B, Fekete C, Slagboom PE, van der Grond J, Demeneix BA, Pijl H, Westendorp RG, van Heemst D: Human longevity is characterised by high thyroid stimulating hormone secretion without altered energy metabolism. Sci Rep 2015;5:11525.

10 Martínez-Sánchez N, Seoane-Collazo P, Contreras C, Varela L, Villarroya J, Rial-Pensado E, Buqué X, Aurrekoetxea I, Delgado TC, Vázquez-Martínez R, González-García I, Roa J, Whittle AJ, Gomez-Santos B, Velagapudi V, Tung YCL, Morgan DA, Voshol PJ, Martínez de Morentin PB, López-González T et al.: Hypothalamic AMPK-ER Stress-JNK1 Axis Mediates the Central Actions of Thyroid Hormones on Energy Balance. Cell Metab 2017;26:212-229.

-11 Tinahones FJ, Coín Aragüez L, Murri M, Oliva Olivera W, Mayas Torres MD, Barbarroja N, Gomez Huelgas R, Malagón MM, El Bekay R: Caspase induction and BCL2 inhibition in human adipose tissue: a potential relationship with insulin signaling alteration. Diabetes Care 2013;36:513-521.

12 Moreno-Navarrete JM, Moreno M, Vidal M, Ortega F, Ricart W, Fernández-Real JM: DBC1 is involved in adipocyte inflammation and is a possible marker of human adipose tissue senescence. Obesity (Silver Spring) 2015;23:519-522. 


\section{Cellular Physiology Cell Physiol Biochem 2018;51:142-153 and Biochemistry \begin{tabular}{l|l} 
DOI: 10.1159/000495170 & (c) 2018 The Author(s). Published by S. Karger AG, Basel \\
Publisned
\end{tabular} \\ Moreno-Navarrete et al.: TSH and Adipose Tissue Senescence}

13 Ortega FJ, Moreno-Navarrete JM, Mayas D, Serino M, Rodriguez-Hermosa JI, Ricart W, Luche E, Burcelin R, Tinahones FJ, Frühbeck G, Mingrone G, Fernández-Real JM: Inflammation and insulin resistance exert dual effects on adipose tissue tumor protein 53 expression. Int J Obes (Lond) 2014;38:737-745.

-14 Moreno-Navarrete JM, Ortega F, Sabater M, Ricart W, Fernández-Real JM: Telomere length of subcutaneous adipose tissue cells is shorter in obese and formerly obese subjects. Int J Obes (Lond) 2010;34:1345-1348.

15 el Bouazzaoui F, Henneman P, Thijssen P, Visser A, Koning F, Lips MA, Janssen I, Pijl H, Willems van Dijk K, van Harmelen V: Adipocyte telomere length associates negatively with adipocyte size, whereas adipose tissue telomere length associates negatively with the extent of fibrosis in severely obese women. Int J Obes (Lond) 2014;38:746-749.

16 Moreno-Navarrete JM, Moreno M, Ortega F, Xifra G, Hong S, Asara JM, Serrano JCE, Jové M, Pissios P, Blüher M, Ricart W, Portero-Otin M, Fernández-Real JM: TSHB mRNA is linked to cholesterol metabolism in adipose tissue. FASEB J 2017;31:4482-4491.

17 Moreno-Navarrete JM, Ortega FJ, Rodríguez-Hermosa JI, Sabater M, Pardo G, Ricart W, Fernández-Real JM: OCT1 Expression in adipocytes could contribute to increased metformin action in obese subjects. Diabetes 2011;60:168-176.

18 López M, Seoane L, Tovar S, Señarís RM, Diéguez C: Thyroid status regulates CART but not AgRP mRNA levels in the rat hypothalamus. Neuroreport 2002;13:1775-1779.

19 López M, Seoane L, Señarís RM, Diéguez C: Prepro-orexin mRNA levels in the rat hypothalamus, and orexin receptors mRNA levels in the rat hypothalamus and adrenal gland are not influenced by the thyroid status. Neurosci Lett 2001;300:171-175.

-20 López M, Varela L, Vázquez MJ, Rodríguez-Cuenca S, González CR, Velagapudi VR, Morgan DA, Schoenmakers E, Agassandian K, Lage R, Martínez de Morentin PB, Tovar S, Nogueiras R, Carling D, Lelliott C, Gallego R, Oresic M, Chatterjee K, Saha AK, Rahmouni K, Diéguez C, Vidal-Puig A: Hypothalamic AMPK and fatty acid metabolism mediate thyroid regulation of energy balance. Nat Med 2010;16:1001-1008.

-21 Jové M, Ayala V, Ramírez-Núñez O, Serrano JC, Cassanyé A, Arola L, Caimari A, Del Bas JM, Crescenti A, Pamplona R, Portero-Otín M: Lipidomic and metabolomic analyses reveal potential plasma biomarkers of early atheromatous plaque formation in hamsters. Cardiovasc Res 2013;97:642-652.

22 Comas F, Lluch A, Sabater M, Latorre J, Ortega F, Ricart W, López M, Fernández-Real JM, Moreno-Navarrete JM: Adipose tissue TSH as a new modulator of human adipocyte mitochondrial function. Int J Obes (Lond) 2018 DOI: 10.1038/s41366-018-0203-1.

-23 Cutler RG, Thompson KW, Camandola S, Mack KT, Mattson MP: Sphingolipid metabolism regulates development and lifespan in Caenorhabditis elegans. Mech Ageing Dev 2014;143-144:9-18.

24 Park JH, Kang HJ, Lee YK, Kang H, Kim J, Chung JH, Chang JS, McPherron AC, Lee SB: Inactivation of EWS reduces PGC- $1 \alpha$ protein stability and mitochondrial homeostasis. Proc Natl Acad Sci U S A 2015;112:60746079.

-25 Stanford KI, Middelbeek RJ, Townsend KL, Lee MY, Takahashi H, So K, Hitchcox KM, Markan KR, Hellbach K, Hirshman MF, Tseng YH, Goodyear LJ: A novel role for subcutaneous adipose tissue in exercise-induced improvements in glucose homeostasis. Diabetes 2015;64:2002-2014.

-26 Jahansouz C, Serrot FJ, Frohnert BI, Foncea RE, Dorman RB, Slusarek B, Leslie DB, Bernlohr DA, Ikramuddin S: Roux-en-Y Gastric Bypass Acutely Decreases Protein Carbonylation and Increases Expression of Mitochondrial Biogenesis Genes in Subcutaneous Adipose Tissue. Obes Surg 2015;25:2376-2385.

27 Zhao Y, Ling F, Griffin TM, He T, Towner R, Ruan H, Sun XH: Up-regulation of the Sirtuin 1 (Sirt1) and peroxisome proliferator-activated receptor $\gamma$ coactivator-1 $\alpha$ (PGC- $1 \alpha$ ) genes in white adipose tissue of Id1 protein-deficient mice: implications in the protection against diet and age-induced glucose intolerance. J Biol Chem 2014;289:29112-29122.

-28 Jukarainen S, Heinonen S, Rämö JT, Rinnankoski-Tuikka R, Rappou E, Tummers M, Muniandy M, Hakkarainen A, Lundbom J, Lundbom N, Kaprio J, Rissanen A, Pirinen E, Pietiläinen KH: Obesity Is Associated With Low NAD(+)/SIRT Pathway Expression in Adipose Tissue of BMI-Discordant Monozygotic Twins. J Clin Endocrinol Metab 2016;101:275-283.

-29 Rutanen J, Yaluri N, Modi S, Pihlajamäki J, Vänttinen M, Itkonen P, Kainulainen S, Yamamoto H, Lagouge M, Sinclair DA, Elliott P, Westphal C, Auwerx J, Laakso M: SIRT1 mRNA expression may be associated with energy expenditure and insulin sensitivity. Diabetes 2010;59:829-835. 


\section{Cellular Physiology Cell Physiol Biochem 2018;51:142-153

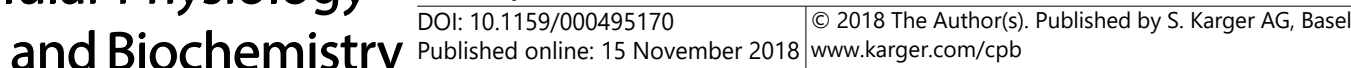

30 Huang J, Gan Q Han L, Li J, Zhang H, Sun Y, Zhang Z, Tong T: SIRT1 overexpression antagonizes cellular senescence with activated ERK/S6k1 signaling in human diploid fibroblasts. PLoS One 2008;3:e1710.

-31 Ho C, van der Veer E, Akawi O, Pickering JG: SIRT1 markedly extends replicative lifespan if the NAD+ salvage pathway is enhanced. FEBS Lett 2009;583:3081-3085.

-32 Villaret A, Galitzky J, Decaunes P, Estève D, Marques MA, Sengenès C, Chiotasso P, Tchkonia T, Lafontan M, Kirkland JL, Bouloumié A: Adipose tissue endothelial cells from obese human subjects: differences among depots in angiogenic, metabolic, and inflammatory gene expression and cellular senescence. Diabetes 2010;59:2755-2763.

-33 Yuan HF, Zhai C, Yan XL, Zhao DD, Wang JX, Zeng Q, Chen L, Nan X, He LJ, Li ST, Yue W, Pei XT: SIRT1 is required for long-term growth of human mesenchymal stem cells. J Mol Med (Berl) 2012;90:389-400.

34 Zhao W, Kruse JP, Tang Y, Jung SY, Qin J, Gu W: Negative regulation of the deacetylase SIRT1 by DBC1. Nature 2008;451:587-590.

-35 Li J, Zhang CX, Liu YM, Chen KL, Chen G: A comparative study of anti-aging properties and mechanism: resveratrol and caloric restriction. Oncotarget 2017;8:65717-65729.

-36 Palacios JA, Herranz D, De Bonis ML, Velasco S, Serrano M, Blasco MA: SIRT1 contributes to telomere maintenance and augments global homologous recombination. J Cell Biol 2010;191:1299-1313.

-37 Chu DT, Tao Y: Molecular connections of obesity and aging: a focus on adipose protein 53 and retinoblastoma protein. Biogerontology 2017;18:321-332.

-38 Huang Q Liu M, Du X, Zhang R, Xue Y, Zhang Y, Zhu W, Li D, Zhao A, Liu Y: Role of p53 in preadipocyte differentiation. Cell Biol Int 2014;38:1384-2393.

-39 Molchadsky A, Shats I, Goldfinger N, Pevsner-Fischer M, Olson M, Rinon A, Tzahor E, Lozano G, Zipori D, Sarig R, Rotter V: p53 plays a role in mesenchymal differentiation programs, in a cell fate dependent manner. PLoS ONE 2008;3:e3707.

-40 Molchadsky A, Ezra O, Amendola PG, Krantz D, Kogan-Sakin I, Buganim Y, Rivlin N, Goldfinger N, Folgiero V, Falcioni R, Sarig R, Rotter V: p53 is required for brown adipogenic differentiation and has a protective role against diet-induced obesity. Cell Death Differ 2013;20:774-783.

41 Shimizu I, Yoshida Y, Katsuno T, Tateno K, Okada S, Moriya J, Yokoyama M, Nojima A, Ito T, Zechner R, Komuro I, Kobayashi Y, Minamino T: p53-induced adipose tissue inflammation is critically involved in the development of insulin resistance in heart failure. Cell Metab 2012;15:51-64.

-42 Yahagi N, Shimano H, Matsuzaka T, Najima Y, Sekiya M, Nakagawa Y, Ide T, Tomita S, Okazaki H, Tamura Y, Iizuka Y, Ohashi K, Gotoda T, Nagai R, Kimura S, Ishibashi S, Osuga J, Yamada N: p53 activation in adipocytes of obese mice. J Biol Chem 2003;278:25395-25400.

43 Minamino T, Orimo M, Shimizu I, Kunieda T, Yokoyama M, Ito T, Nojima A, Nabetani A, Oike Y, Matsubara H, Ishikawa F, Komuro I: A crucial role for adipose tissue p53 in the regulation of insulin resistance. Nat Med 2009;15:1082-1087.

44 Vergoni B, Cornejo PJ, Gilleron J, Djedaini M, Ceppo F, Jacquel A, Bouget G, Ginet C, Gonzalez T, Maillet J, Dhennin V, Verbanck M, Auberger P, Froguel P, Tanti JF, Cormont M: DNA damage and the activation of the p53 pathway mediate alterations in metabolic and secretory functions of adipocytes. Diabetes 2016;65:3062-3074.

-45 Bogazzi F, Raggi F, Russo D, Bohlooly YM, Sardella C, Urbani C, Lombardi M, Manetti L, Lupi I, Tornell J, Martino E: Growth hormone is necessary for the p53-mediated, obesity-induced insulin resistance in male C57BL/6J × CBA mice. Endocrinology 2013;154:4226-4236.

46 Homayounfar R, Jeddi-Tehrani M, Cheraghpour M, Ghorbani A, Zand H: Relationship of p53 accumulation in peripheral tissues of high-fat diet-induced obese rats with decrease in metabolic and oncogenic signaling of insulin. Gen Comp Endocrinol 2015;214:134-139.

-47 Kung CP, Leu JI, Basu S, Khaku S, Anokye-Danso F, Liu Q George DL, Ahima RS, Murphy ME: The P72R polymorphism of p53 predisposes to obesity and metabolic dysfunction. Cell Rep 2016;14:2413-2425.

-48 Liu S, Kim T-H, Franklin DA, Zhang Y: Protection against high-fat-diet-induced obesity in MDM2 ${ }^{\mathrm{C} 305 \mathrm{~F}}$ mice due to reduced p53 activity and enhanced energy expenditure. Cell Rep 2017;18:1005-1018.

-49 Killion EA, Reeves AR, El Azzouny MA, Yan QW, Surujon D, Griffin JD, Bowman TA, Wang C, Matthan NR, Klett EL, Kong D, Newman JW, Han X, Lee MJ, Coleman RA, Greenberg AS: A role for long-chain acylCoA synthetase-4 (ACSL4) in diet-induced phospholipid remodeling and obesity-associated adipocyte dysfunction. Mol Metab 2018;9:43-56. 


\section{Cellular Physiology Cell Physiol Biochem 2018;51:142-153

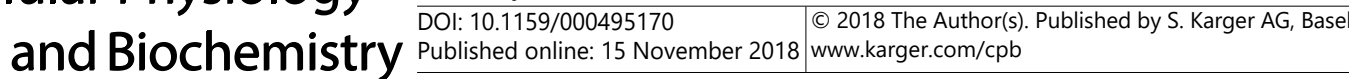 \\ Moreno-Navarrete et al.: TSH and Adipose Tissue Senescence}

-50 Sen N, Satija YK, Das S: PGC-1 $\alpha$, a key modulator of p53, promotes cell survival upon metabolic stress. Mol Cell 2011;44:621-634.

51 Heinonen S, Buzkova J, Muniandy M, Kaksonen R, Ollikainen M, Ismail K, Hakkarainen A, Lundbom J, Lundbom N, Vuolteenaho K, Moilanen E, Kaprio J, Rissanen A, Suomalainen A, Pietiläinen KH: Impaired Mitochondrial Biogenesis in Adipose Tissue in Acquired Obesity. Diabetes 2015;64:3135-3145.

52 Caron M, Auclairt M, Vissian A, Vigouroux C, Capeau J: Contribution of mitochondrial dysfunction and oxidative stress to cellular premature senescence induced by antiretroviral thymidine analogues. Antivir Ther 2008;13:27-38.

53 Mennes E, Dungan CM, Frendo-Cumbo S, Williamson DL, Wright DC: Aging-associated reductions in lipolytic and mitochondrial proteins in mouse adipose tissue are not rescued by metformin treatment. J Gerontol A Biol Sci Med Sci 2014;69:1060-1068.

-54 Ferrandino G, Kaspari RR, Spadaro 0, Reyna-Neyra A, Perry RJ, Cardone R, Kibbey RG, Shulman GI, Dixit VD, Carrasco N: Pathogenesis of hypothyroidism-induced NAFLD is driven by intra- and extrahepatic mechanisms. Proc Natl Acad Sci U S A 2017;114:E9172-E9180. 